Article

\title{
Benefits of Ryegrass on Multicontaminated Soils Part 2: A Green Process to Provide Idrocilamide
}

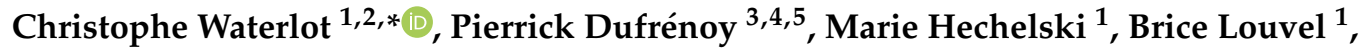 \\ Adam Daïch 5 (iD) and Alina Ghinet ${ }^{3,4,6}$ (i) \\ 1 Laboratoire Génie Civil et géoEnvironnement (LGCgE), Yncréa Hauts-de-France, Institut Supérieur \\ d'Agriculture, 48 Boulevard Vauban, 59046 Lille CEDEX, France; marie.hechelski@yncrea.fr (M.H.); \\ brice.louvel@yncrea.fr (B.L.) \\ 2 Equipe Biotechnologie et Gestion des Agents Pathogènes en Agriculture (BioGAP), Yncréa Hauts-de-France, \\ Institut Supérieur d'Agriculture, 48 Boulevard Vauban, 59046 Lille CEDEX, France \\ 3 Laboratoire de Chimie Durable et Santé, Yncréa Hauts-de-France, Ecole des Hautes Etudes d'Ingénieur, \\ 13 rue de Toul, 59046 Lille CEDEX, France; Pierrick.dufrenoy@yncrea.fr (P.D.); alina.ghinet@yncrea.fr (A.G.) \\ 4 Faculté de Médecine-Pôle Recherche Inserm U995, LIRIC, Université de Lille, CHU de Lille, Place Verdun, \\ 59045 Lille CEDEX, France \\ 5 Normandie Univ., UNILEHAVRE, FR 3038 CNRS, URCOM, 76600 Le Havre, BP: 1123 EA 3221, INC3M \\ CNRS-FR 3038, UFR ST 25 rue Philipe Lebon, F-76063 Le Havre CEDEX, France; adam.daich@univ-lehavre.fr \\ 6 Faculty of Chemistry, 'Alexandru Ioan Cuza' University of Iasi, Bd. Carol I nr. 11, 700506 Iasi, Romania \\ * Correspondence: christophe.waterlot@yncrea.fr
}

Received: 19 August 2019; Accepted: 22 November 2019; Published: 26 November 2019

\begin{abstract}
A restoration of highly contaminated garden soil is proposed as a greener alternative to the production of vegetables. Depending on potentially toxic elements and their concentration, ryegrass shoots accumulate these elements in sufficient quantity to be used as a catalyst in organic synthesis. The analysis of $\mathrm{Cd}, \mathrm{Pb}, \mathrm{Zn}, \mathrm{Cu}, \mathrm{Fe}, \mathrm{Mn}$, and $\mathrm{Al}$ in ashes issued from the calcination of ryegrass shoots revealed that the concentration of $Z n$ was highest $\left(>7000 \mathrm{mg} \mathrm{kg}^{-1}\right)$. The ratios between potential Lewis acids $(\mathrm{Zn}, \mathrm{Cu}, \mathrm{Fe}, \mathrm{Mn}$, and $\mathrm{Al}$ ) to carcinogenic metals $(\mathrm{Cd}$ or $\mathrm{Pb}$ ) were $191 \pm 7$ for $\mathrm{LA} / \mathrm{Cd}$ and $235 \pm 13$ for $\mathrm{LA} / \mathrm{Pb}$, making the shoots of ryegrass suitable for the production of $\mathrm{Zn}$-rich polymetallic biosourced catalysts. This material was used in the synthesis of idrocilamide under free-solvent condition, providing the drug in a good yield (69.9\%). Data show that a limitation of waste, a maximization of the material incorporation in the process, a minimization of the steps, and an optimization of the stoichiometric factor are the main innovative factors in the current process in comparison with those previously reported.
\end{abstract}

Keywords: ryegrass; green chemistry; biosourced catalyst; synthesis; metrics

\section{Introduction}

The problem of multi-contaminated sites by inorganic pollutants is a worldwide concern since the potential toxic elements (PTEs) are persistent and ubiquitous in the earth's environment. Among the 10 million sites that have been reported as being contaminated, $50 \%$ are contaminated by PTEs [1]. In addition to fertilizer application and atmospheric deposition, contaminated soils from urban areas (recreational areas, lawns, and kitchen gardens) are often subjected to other sources of contamination such as traffic emission, urban effluent, waste disposal, and the addition of ashes from wood- and coal-burning. These dangerous and widespread sources of contamination are of major concern since (i) it is recognized that the bioavailability of PTEs from anthropogenic contamination is higher than geogenic sources [2], (ii) kitchen gardens (shared, allotment, and private gardens) are often more contaminated than agricultural soils [3-5], (iii) homegrown vegetables, fruiting vegetables, and fresh 
herbs do not comply with the European legislation due to the accumulation of PTEs [6-13], (iv) the health of people living in urban areas and the surrounding ecosystems are affected [14-16]. In this context, some gardeners have taken the decision to change their cultural practices whereas others decided to stop gardening and to sow ryegrass. This plant is described as a suitable plant for the revegetation of contaminated soils from metallurgical sites, able to remove $\mathrm{Cd}$ from soils, and to survive in contaminated acidic soils [17-20]. For these reasons, this study focuses on the possibility of finding a new valorization way for contaminated shoots of ryegrass.

Currently, people leave contaminated grass clipping in their own lawn as mulch and/or their own garden as compost or get them disposed. Although the preferred disposal route in EU countries is composting (improvement of microbiological, biochemical, physicochemical, and agronomical properties of soils [21-24]), some drawbacks in using contaminated composts have been highlighted [25-33]. Thus, to avoid the disposal of the harvested contaminated biomass, physical and/or chemical processes were developed after the incineration of this biomass, thus enabling the recycling of nutrients and/or PTEs. Three strategies, called agromining, phytomining, and ecocatalysis have been recently described as promising technologies in recovering PTEs from presently untapped secondary resources [34-39]. The use of polluted ashes as ecocatalysts seems to be very interesting since one industrial challenge is to replace metal-chlorides used in organic synthesis as Lewis acids (MCln; Equation (1)). They are toxic for humans, react with water to produce $\mathrm{HCl}$ (Equation (1)), and they have to be removed from organic products, thus generating chemical waste. These ecocatalysts were described as new eco-friendly plant-based green Lewis acid catalysts [34-37] and may be considered as part of the progress in sustainable chemistry. This has become ever truer since Professors Anastas, Warner, and Zimmerman stated the 12 Principles of Green Chemistry and the 12 principles of green engineering in which this concept is embodied $[40,41]$.

$$
\mathrm{MCl}_{\mathrm{n}}+\mathrm{nH}_{2} \mathrm{O} \rightarrow \mathrm{nHCl}+\mathrm{M}(\mathrm{OH})_{\mathrm{n}} \stackrel{\mathrm{H}^{+}}{\rightarrow} \mathrm{nH}_{2} \mathrm{O}+\mathrm{M}^{\mathrm{n}+}
$$

In the first part of this study [42], we demonstrated that the shoots of ryegrass may have a potential interest in organic chemistry. Based on our previous findings and considering the 12 principles of green chemistry and green engineering, a new experimental design was conducted and a new valorization way of contaminated ryegrass shoots was proposed. A biosourced catalyst was thus produced from contaminated ryegrass and was used to synthesize idrocilamide. This organic compound is the main ingredient of several drugs with anti-inflammatory and muscle relaxing properties (e.g., Srilane®).

\section{Materials and Methods}

\subsection{Perennial Ryegrass Shoots Production}

A pot (18 cm in diameter, $14 \mathrm{~cm}$ height) experiment was established in a greenhouse for 8 weeks using the soil G1 described in the first part of the current study [42]. Containers $(n=6)$ with $2 \mathrm{~kg}$ of soil G1 were placed in the greenhouse with day/night temperatures of $28 \pm 5 / 10 \pm 5^{\circ} \mathrm{C}$ (corresponding to April-July). Tap water (electrical conductivity, $10 \mathrm{dS} \mathrm{m}^{-1} ; \mathrm{pH}, 7$; Cd concentration, $0.9 \mu \mathrm{g} \mathrm{L}^{-1}$, and $\mathrm{Pb}$ concentration, $2.1 \mu \mathrm{g} \mathrm{L}^{-1}$ ) was added in each pot to maintain the soil water content at $60 \%$ field capacity for two months. After this period, ryegrass seeds (Lolium perenne L.; $1.5 \mathrm{~g}$ ) were sown, and the shoots were harvested 8 weeks after sowing. The total fresh shoot biomass was $408 \mathrm{~g}$ ( $68 \pm 7 \mathrm{~g}$ per container; $n=6$ ).

\subsection{Digestion and Determination of PTE Concentrations in the Biomass of Shoots}

Air-dried plants were crushed with a knife crusher (Grindomix GM 200, Retsch) and sieved to pass $315 \mu \mathrm{m}$. Subsamples $(0.3 \mathrm{~g} ; n=6)$ were placed in a $50-\mathrm{mL}$ digestion tube, and $5 \mathrm{~mL}$ of $\mathrm{HNO}_{3}$ $(69 \%)$ was added. The mixture was firstly digested at $65 \pm 5^{\circ} \mathrm{C}$ for $20 \mathrm{~min}$, and then, at $90 \pm 5^{\circ} \mathrm{C}$ for 45 min (HotBlock ${ }^{\mathrm{TM}}$ Environmental Express ${ }^{\circledR} \mathrm{SC} 100$, Charleston, SC, USA). After cooling, $1.2 \mathrm{~mL}$ of deionized water and $1.8 \mathrm{~mL}$ of $\mathrm{H}_{2} \mathrm{O}_{2}$ solution ( $30 \%$ ) were slowly added, and the reaction medium was 
heated at $90 \pm 5^{\circ} \mathrm{C}$ for $45 \mathrm{~min}$. After cooling, the volume was adjusted to $25 \mathrm{~mL}$ with deionized water. Each digested-solution was filtered over an acetate Millipore membrane $(0.45 \mu \mathrm{m}$ porosity) and stored in acid-washed plastic bottles at $4{ }^{\circ} \mathrm{C}$ prior to analysis. The concentrations of PTEs in certified samples and shoots biomass were determined by absorption spectrometry (FAAS; AA-6800 Shimadzu, Tokyo, Japan) following the recommendation described in detail in the literature [43-45]. Limits of detection and quantification are detailed in the first part of the current study [42].

\subsection{Preparation of Biosourced Catalyst}

Air-dried shoots of ryegrass (70 g) were thermally treated in a muffle furnace (Nabertherm P330, Lilienthal, Germany) under airflow. Two warm-up phases were defined: from 20 to $250{ }^{\circ} \mathrm{C}$ in $30 \mathrm{~min}$ and stabilization for $1 \mathrm{~h}$ and from 250 to $500^{\circ} \mathrm{C}$ in $2 \mathrm{~h}$ and stabilization for $8 \mathrm{~h}$. After an overnight cooling period, the ashes were put in a flask, fitted with an air condenser, and a $2 \mathrm{M} \mathrm{HCl}$ solution was slowly added in a ratio $1 / 10$. The mixture was stirred and heated at $70^{\circ} \mathrm{C}$ for $2 \mathrm{~h}$. After cooling, the solution and the residue were separated using celite, and the solution was concentrated to obtain a solid residue. After drying at $80^{\circ} \mathrm{C}$ for $12 \mathrm{~h}$, the yellow dry residue was mixed with montmorillonite K10 (MK10) in order to obtain a solid. The molar quantity of $\mathrm{Zn}$ in the solid was $1.22 \mathrm{mmol} / \mathrm{g}$ MK10. The solid mixture was stirred at room temperature for $5 \mathrm{~h}$ after adding methanol. In the last step, the solid was filtered and was thermally activated at $120^{\circ} \mathrm{C}[46,47]$.

\subsection{Synthesis of Idrocilamide under Green Conditions}

Methyl cinnamate $(\mathbf{1} ; 0.5 \mathrm{~g})$ and 2-aminoethanol $(2 ; 0.19 \mathrm{~g})$ were mixed together with the biosourced catalyst (BioCat; $126 \mathrm{mg}$ ) at $70{ }^{\circ} \mathrm{C}$ for $24 \mathrm{~h}$ under solvent-free conditions (Figure 1). After cooling to room temperature, the mixture was filtered and the compound was purified on flash chromatography (EtOAc: $n$-Heptane, 0:1 to 1:1). ${ }^{1} \mathrm{H}-\mathrm{NMR}$ spectrum was run on a Varian 400-MR spectrometer with tetramethylsilane (TMS) as an internal standard at $25^{\circ} \mathrm{C}$ in order to control the purity of idrocilamide (3; data not shown).

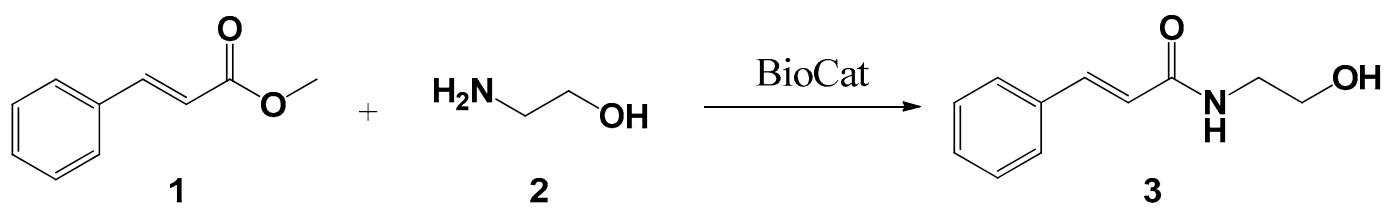

Figure 1. Amidation of methyl cinnamate using the biosourced catalyst (Biocat).

\subsection{Green Chemistry Metrics}

The atom economy is a theoretical value described in the literature and expressed according to Equation (2) [48]. From a practical point of view, this metric is related to the percentage of reactants engaged in the reaction process that may be considered as waste materials.

$$
\mathrm{AE}=\frac{\text { Molecular weight of the isolated product }}{\text { Sum of the molecular weights of the reactants }} \times 100
$$

The E-factor is calculated following Equation (3) [49]. For researchers and industrials, this metric measures how much material enters the production site and how much leaves as product and/or waste materials.

$$
\mathrm{E}-\text { factor }=\frac{\text { Mass of waste }}{\text { Mass of product }}
$$

The reaction mass efficiency is calculated from Equation (4) [50].

$$
\mathrm{RME}=\frac{\text { Isolated weight of the isolated product }}{\text { Sum of the weights of the reactants }}
$$


The stoichiometric factor (Equation (5)) highlights the difference between the reaction conducted in the process studied and this reaction when the reactants are used in a stoichiometric condition [50].

$$
\mathrm{SF}=1-\frac{\text { Sum of the weights of the reactants }- \text { sum of the weights of the reactants in a stoichiometric process }}{\text { Sum of the weights of the reactants in a stoichiometric process }}
$$

\section{Results and Discussion}

\subsection{Concentration of PTEs in the Ashes of Ryegrass Shoots}

The concentrations of PTEs in ashes of ryegrass are summarized in Table 1. The average concentrations of PTEs in ashes ranged from 40 to $7543 \mathrm{mg} \mathrm{kg}^{-1}$. The concentrations of PTEs in the ryegrass were in the following ascending order: $\mathrm{Pb}<\mathrm{Cd}<\mathrm{Cu}<\mathrm{Fe}<\mathrm{Al}<\mathrm{Mn}<\mathrm{Zn}$. It is worth mentioning that the concentrations of carcinogenic metals $(\mathrm{Cd}$ and $\mathrm{Pb})$ were the lowest in comparison with those of metals, called "metals of interest" in the current study due to their application in a great number of organic reactions [35]. Among the studied PTEs, Zn appeared as the most phytoavailable. Since salts of $\mathrm{Zn}, \mathrm{Cu}, \mathrm{Mn}, \mathrm{Fe}$, and $\mathrm{Al}$ are potential Lewis acids (LA), the ratios of $\mathrm{LA} / \mathrm{Cd}$ and $\mathrm{LA} / \mathrm{Pb}$ values were calculated. As shown in Table 1, these ratios were $152.8 \pm 5.5$ and $188.3 \pm 10.4$, respectively. These results suggest that shoots of ryegrass may be considered as suitable biomass to synthesize molecules of interest via green chemistry and engineering processes after their conversion into biosourced catalysts (called Zn-BioCat).

Table 1. Concentration of potential toxic elements (PTEs) (mean \pm standard deviation in $\mathrm{mg} \mathrm{kg}^{-1}$; $n=6)$ in the ashes of ryegrass shoots and ratios $[\mathrm{Zn}] /[\mathrm{M}]$.

\begin{tabular}{cccccccc}
\hline Element & $\mathbf{C d}$ & $\mathbf{P b}$ & $\mathbf{Z n}$ & $\mathbf{C u}$ & $\mathbf{M n}$ & $\mathbf{F e}$ & $\mathbf{A l}$ \\
\hline Concentration & $49 \pm 1$ & $40 \pm 1$ & $7543 \pm 222$ & $69 \pm 4$ & $908 \pm 41$ & $303 \pm 8$ & $597 \pm 133$ \\
Ratio $[\mathrm{Zn}] /[\mathrm{M}]$ & $152.8 \pm 5.5$ & $188.3 \pm 10.4$ & 1 & $109.1 \pm 9.4$ & $8.3 \pm 0.4$ & $24.9 \pm 1.0$ & $13.2 \pm 3.3$ \\
\hline
\end{tabular}

\subsection{Synthesis of Idrocilamide Using Zn-BioCat}

As described in the previous section, idrocilamide was synthesized from methyl cinnamate (1), 2-aminoethanol (2), and $\mathrm{Zn}$-BioCat. This reaction was conducted under a solvent-free condition at $70^{\circ} \mathrm{C}$ for $24 \mathrm{~h}$. Few studies reported the synthesis of this compound in the literature. Briefly, idrocilamide was first produced by Guan et al. [51] from 4 reactants using dichloromethane $\left(\mathrm{CH}_{2} \mathrm{Cl}_{2}\right)$ as a solvent and then, by De Sarkar et al. [52] from 5 reactants in tetrahydrofuran (THF) as a solvent. Due to the high number of reactants, the use of solvents $\left(\mathrm{CH}_{2} \mathrm{Cl}_{2}\right.$ and THF), which are not classified as green solvents and their effects on human health [53,54], the proposed route was not compared to the reaction schemes of Guan et al. [51] and De Sarkar et al. [50]. In contrast, our method was compared to the procedure of Garg and Milton [55] in which the authors used the same reactants as those presented in Figure 1 and also sodium carbonate $\left(\mathrm{Na}_{2} \mathrm{CO}_{3}\right)$ in methanol. The current strategy was also compared to the recent procedure described in Dufrénoy et al. [56] in which the authors used zinc chloride $\left(\mathrm{ZnCl}_{2}\right)$ as a Lewis acid catalyst. These comparisons were made using metrics that are usually selected to evaluate the efficiency of chemical processes via the environmental and technical improvements. To mention only the most relevant metrics, yield, carbon efficiency, mass efficiency, environmental factor, and stoichiometric factor were calculated from the conditions used by the authors and those related to our procedure. The results are summarized in Table 2.

Table 2. Metrics associated with the determination of environmental factors.

\begin{tabular}{cccccc}
\hline Method & Yield (\%) & Atom Economy (\%) & Waste (\%) & E-factor & RME (\%) \\
\hline Garg and Milton [55] & 86.6 & 58.0 & 41.9 & 0.72 & 28.9 \\
Dufrénoy et al. [56] & 65.0 & 53.1 & 46.9 & 0.88 & 53.9 \\
This study & 69.9 & 85.7 & 14.3 & 0.17 & 59.7 \\
\hline
\end{tabular}


Yields of the reaction were between $65 \%$ and $86.6 \%$, depending on the experimental conditions. Although the reaction yield from the current study was $5 \%$ higher than that obtained by Dufrénoy et al. [56], it was 16.7\% lower than that from the study of Garg and Milton [52]. Nevertheless, it is worth mentioning that $\mathrm{Zn}$-BioCat was reused after its liquid-solid filtration up to 5 runs without any significant loss of yield, which was up to $77 \%$. This result fortifies the idea that it might be possible to use the unreacted reagents from one run to another or to conduct the reaction under continuous flow using a fixed bed plug-flow quartz reactor [57].

The atom economy of both routes described in the literature were $58.0 \%$ and $53.1 \%$ (Table 2). These results are mainly explained by the utilization of catalysts, $\mathrm{Na}_{2} \mathrm{CO}_{3}$ [55] and $\mathrm{ZnCl}_{2}$ [56], both of them requiring a post-reaction treatment for their elimination. For instance, $\mathrm{ZnCl}_{2}$ treatment may present risks related to the release of $\mathrm{HCl}$ vapors resulting from the reaction between $\mathrm{ZnCl}_{2}$ and water during the hydrolysis process. In our procedure, the atom economy was $85.7 \%$. This value is explained by the recycling and reuse of our $\mathrm{Zn}$-BioCat without significant loss of activity and with reaction time-saving. The first consequence is the low production of waste using Zn-BioCat (14.3\%) in comparison with the other two methods ( $41.9 \%$ and $46.9 \%$, respectively). This may present a great economic interest for industries and may contribute to environment protection. The second consequence is related to the very low value of the E-factor, 0.17 for the proposed method (instead of 0.72 and 0.88 in the two others). This result confirms that our procedure fits into a context of waste minimization and resource efficiency in chemical manufacturing.

Finally, the reaction mass efficiency of Garg's reaction was $28.9 \%$, which means that $71.1 \%$ of the weights of the reactants used in the reaction were not inserted in idrocilamide 3 . In comparison with the study of Dufrénoy et al. [56], a 9.7\% increase of RME was highlighted using Zn-BioCat instead of $\mathrm{ZnCl}_{2}(59.7 \%$ vs. $53.9 \%)$, indicating that $40.3 \%$ of reactants used in the reaction described in Figure 1 were not inserted in idrocilamide 3 . With the same idea, the stoichiometric factor (SF) was equal to 1.75 for the reaction described by Garg and Milton [55], indicating that $75 \%$ of the weights of the reactants were used in excess by the authors. This metric was 1.03 and 1.00 in the process described by Dufrénoy et al. [56] and in the current study, respectively, demonstrating that no limiting and excess reactants were used in the process. It is worth noting that metrics described in Table 2 do not take into account the energy necessary for the thermal process related to the preparation of the ecocatalyst and to the synthesis of idrocilamide. In comparison with the methods described in the literature for the preparation of the target molecule [55,56], the energy costs are similar since the operatory conditions in terms of temperature and duration are analogous. In contrast, ash production needs high thermal energy demand. For this reason, contaminated ashes should be recovered from industries that used biomass to produce energy, thus enabling the heating of buildings. This should contribute to avoiding unnecessary use of energy for the preparation of ecocatalysts.

From a theoretical point of view, based on results obtained in the current study, $3 \mathrm{~kg}$ of ashes are necessary to produce $1 \mathrm{~kg}$ of idrocilamide per run. This corresponds to a mass of fresh shoot biomass of about $30 \mathrm{~kg}$. In previous studies [58,59], heterogeneous catalysts from hyperaccumulators were used several times without any loss of catalytic activity. In the current study, Zn-BioCat was also reused 4 times, and it conserved its efficiency. Consequently, $5 \mathrm{~kg}$ idrocilamide should be produced by using 3 $\mathrm{kg}$ of contaminated ashes. Further studies are needed to inspect the recyclability of our $\mathrm{Zn}$-BioCat in a scale-up production of idrocilamide (a semi-industrial process). Furthermore, it could be interesting to study the reactivity of the biosourced catalyst in the synthesis of idrocilamide derivatives. 


\section{Conclusions}

Shoots of ryegrass grown on contaminated garden soils by $\mathrm{Cd}, \mathrm{Pb}$, and $\mathrm{Zn}$ were transformed into a biosourced catalyst. This product is a $\mathrm{Zn}$-enriched material since the average concentration of $\mathrm{Zn}$ in ashes is $7543 \mathrm{mg} \mathrm{kg}^{-1}$. The utilization of this catalyst in the synthesis of idrocilamide was successful since the product was obtained in 69.9\% yield under green conditions (solvent-free, without post-reaction treatment of the catalyst, reusable catalyst). Moreover, the limitation of waste, a maximization of material incorporation in the process, a minimization of the steps, and optimization of the stoichiometric factor were demonstrated by means of metrics related to the 12 principles of the green chemistry and engineering.

Author Contributions: Formal analysis, Investigation, Methodology, C.W., M.H., P.D., A.G.; Writing-original draft and editing, C.W., A.G.; Writing-review, M.H., P.D., B.L., A.D.

Funding: The authors warmly thank the "Fondation de la Catho de Lille, France" and Yncréa Hauts-de-France for the financial support of this work.

Conflicts of Interest: The authors declare no conflict of interest.

\section{References}

1. USEPA. Cleaning up the Nation's Hazardous Wastes Sites; USEPA: Washington, DC, USA, 2014.

2. Kabata-Pendias, A.; Pendias, H. Biogeochemistry of Trace Elements, 2nd ed.; Polish Scientific Publishing Company: Warsaw, Poland, 1999.

3. Douay, F.; Pruvot, C.; Roussel, H.; Ciesielski, H.; Fourrier, H.; Proix, N.; Waterlot, C. Contamination of urban soils in an area of Northern France polluted by dust emissions of two smelters. Water Air Soil Pollut. 2008, 188, 247-260. [CrossRef]

4. Douay, F.; Pruvot, C.; Waterlot, C.; Fritsch, C.; Fourrier, H.; Loriette, A.; Bidar, G.; Grand, C.; de Vaufleury, A.; Scheifler, R. Contamination of woody habitat soils around a former lead smelter in the North of France. Sci. Total Environ. 2009, 407, 5564-5577. [CrossRef] [PubMed]

5. Pelfrêne, A.; Waterlot, C.; Douay, F. Influence of land use on human bioaccessibility of metals in smelter-impacted soils. Environ. Pollut. 2013, 178, 80-88. [CrossRef] [PubMed]

6. Douay, F.; Pelfrêne, A.; Planque, J.; Fourrier, H.; Richard, A.; Roussel, H.; Girondelot, B. Assessment of potential health risk for inhabitants living near a former lead smelter. Part 1: Metal concentrations in soils, agricultural crops, and homegrown vegetables. Environ. Monit. Assess. 2013, 185, 3665-3680. [CrossRef] [PubMed]

7. Augustsson, A.; Uddh-Söderberg, T.; Hogmalm, K.J.; Filipsson, M.E.M. Metal uptake by homegrown vegetables-The relative importance in human health risk assessments at contaminated sites. Environ. Res. 2015, 138, 181-190. [CrossRef] [PubMed]

8. Augustsson, A.; Uddh-Söderberg, T.; Filipsson, M.; Helmfrid, I.; Berglund, M.; Karlsson, H.; Hogmalm, J.; Karlsson, A.; Alriksson, S. Challenges in assessing the health risks of consuming vegetables in metal-contaminated environments. Environ. Int. 2018, 113, 269-280. [CrossRef]

9. Ávila, P.F.; da Silva, E.F.; Candeias, C. Health risk assessment through consumption of vegetables rich in heavy metals: The case study of the surrounding villages from Panasqueira mine, central Portugal. Environ. Geochem. Health 2017, 39, 565-589. [CrossRef]

10. Ferri, R.; Hashim, D.; Smith, D.R.; Guazzetti, S.; Donna, F.; Ferretti, E.; Curatolo, M.; Moneta, C.; Beone, G.M.; Lucchini, R.G. Metal contamination of home garden soils and culativated vegetables in the province of Brescia, Italy: Implications for human exposure. Sci. Total Environ. 2015, 518, 507-517. [CrossRef]

11. Pančeveski, Z.; Stafilov, T.; Bačeva, K. Distribution of heavy metals in the garden soil and vegetables grown in the vicinity of lead and zinc smelter plant. J. Sci. Eng. Res. 2016, 3, 1-11.

12. Pelfrêne, A.; Douay, F.; Richard, A.; Roussel, H.; Girondelot, B. Assessment of potential health risk for inhabitants living near a former lead smelter. Part2: Site-specific human health risk assessment of $\mathrm{Cd}$ and $\mathrm{Pb}$ contamination in kitchen gardens. Environ. Monit. Assess. 2013, 185, 2999-3012. [CrossRef] 
13. Pelfrêne, A.; Sahmer, K.; Waterlot, C.; Douay, F. From environmental and social data acquisition to assessment of gardeners' exposure: Feedback in an urban context highly contaminated with metals. Environ. Sci. Pollut. Res. 2019. [CrossRef] [PubMed]

14. Wong, C.S.C.; Li, X.; Thorthon, I. Urban environmental geochemistry of trace metals. Environ. Pollut. 2006, 142, 1-16. [CrossRef] [PubMed]

15. Luo, X.S.; Yu, S.; Zhu, Y.G.; Li, X.D. Trace metal contamination in urban soils of China. Sci. Total Environ. 2012, 421, 17-30. [CrossRef] [PubMed]

16. Ettler, V. Soil contamination near non-ferrous metal smelters: A review. Appl. Geochem. 2016, 64, 56-74. [CrossRef]

17. Jia, Y.; Tang, S.; Wang, R.; Ju, X.; Ding, Y.; Tu, S.; Smith, D.L. Effects of elevated on growth, photosynthesis, elemental composition, antioxidant level, and phytochelatin concentration in Lolium multiforum and Lolium perenne under Cd stress. J. Hazard. Mater. 2010, 180, 384-394. [CrossRef]

18. Arienzo, M.; Adamo, P.; Cozzolino, V. The potential of Lolium perenne for revegetation of contaminated soil from a metallurgical site. Sci. Total Environ. 2004, 319, 13-25. [CrossRef]

19. Sterckeman, T.; Duquene, L.; Perriguey, J.; Morel, J.L. Quantifying the effect of rhizosphere processes on the availability on soil cadmium and zinc. Plant Soil 2005, 276, 335-345. [CrossRef]

20. Rees, F.; Germain, C.; Sterckeman, T.; Morel, J.L. Plant growth and metal uptake by a non-hyperaccumulating species (Lolium perenne L.) and a Cd-Zn hyperaccumulator (Noccaea caerulrscens) in contaminated soils amended with biochar. Plant Soil 2015, 395, 57-73. [CrossRef]

21. Convertini, G.; Ferri, D.; Montemurro, F.; Maiorana, M. Effects of municipal solid waste compost on soils cropped with tomato and sunflower rotation with durum wheat. In Proceedings of the ISCO 2004-13th International Soil Conservation Organisation Conference, Brisbane, Australia, 4-8 July 2004.

22. Tittarelli, F.; Petruzzelli, G.; Pezzarossa, B.; Civilini, M.; Benedetti, A.; Sequi, P. Quality and agronomic use of compost. Waste Manag. Ser. 2007, 8, 119-157.

23. Strachel, R.; Wyszkowska, J.; Baémaga, M. The role of compost in stabilizing the microbiological and biochemical properties of zinc-stressed soil. Water Air Soil Pollut. 2017, 228, 349-364. [CrossRef]

24. Bakshi, S.; Banik, C.; He, Z. Monitoring and management. In Managing Soil Health for Sustainable Agriculture; Reicosky, D., Ed.; Burleigh Dodds Science Publishing: Cambridge, UK, 2018; Volume 2.

25. Bong, C.P.C.; Lim, L.Y.; Ho, W.S.; Lim, J.S.; Klemes, J.J.; Towprayoon, S.; Ho, C.S.; Lee, C.T. A review on the global warming potential of cleaner composting and mitigation strategies. J. Clean. Prod. 2017, 146, 149-157. [CrossRef]

26. Harisson, E.Z. Health impact of composting air emission. Biocycle 2007, 48, 44-50.

27. Smith, S.R. A critical review of the bioavailability and impacts of heavy metals in municipal solid waste composts compared to sewage sludge. Environ. Int. 2009, 35, 142-156. [CrossRef] [PubMed]

28. Smolinska, B. Green waste compost as an amendment during induced phytoextraction of mercury-contaminated soil. Environ. Sci. Pollut. Res. 2015, 22, 3528-3537. [CrossRef] [PubMed]

29. Huang, M.; Zhu, Y.; Li, Z.; Huang, B.; Luo, N.; Liu, C.; Zeng, G. Compost as a soil amendment to remediate heavy metal-contaminated agricultural soils: Mechanisms, efficacy, problems, and strategies. Water Air Soil Pollut. 2016, 227, 359-377. [CrossRef]

30. McBride, M.B.; Shayler, H.A.; Russell-Analli, J.M.; Spliethoff, H.M.; Marquez-Bravo, L.G. Arsenic and lead uptake by vegetable crops grown on an old Orchard site amended with compost. Water Air Soil Pollut. 2015, 226, 265-275. [CrossRef]

31. Edelstein, M.; Ben-Hur, M. Heavy metals and metalloids: Sources, risks and strategies to reduce their accumulation in horticultural crops. Sci. Hortic. 2018, 234, 431-444. [CrossRef]

32. Paltseva, A.; Cheng, Z.; Deeb, M.; Groffman, P.M.; Shaw, R.K.; Maddaloni, M. Accumulation of arsenic and lead in garden-grown vegetables: Factors and mitigation strategies. Sci. Total Environ. 2018, 640, $273-283$. [CrossRef]

33. Chen, J.H.; Wu, J.T. Benefits and Drawbacks of Composting. Food and Fertilizer Technology Center. 2005. Available online: http://www.fftc.agnet.org/library.php?func=view\&id=20110804100401 (accessed on 9 June 2018).

34. Grison, C.; Escande, V.; Biton, J. Ecocatalysis: A New Integrated Approach to Scientific Ecology; Elsevier: Amsterdam, The Netherlands, 2015; 100p. 
35. Hechelski, M.; Ghinet, A.; Louvel, B.; Dufrénoy, P.; Rigo, B.; Daïch, A.; Waterlot, C. From Conventional Lewis acids to heterogeneous montmorillonite $\mathrm{K} 10$, eco-friendly plant-based catalysts used as green Lewis acids. ChemSusChem 2018, 11, 1249-1277. [CrossRef]

36. Deyris, P.A.; Bert, V.; Diliberto, S.; Boulanger, C.; Petit, E.; Legrand, Y.M.; Grison, C. Biosourced polymetallic catalysis: A surprising and efficient means to promote the Knoevenagel condensation. Front. Chem. 2018, 6, 1-9. [CrossRef]

37. Deyris, P.A.; Grison, C. Nature, ecology and chemistry: An unusual combination for a new green catalysis, ecocatalysis. Curr. Opin. Green. Sustain. Chem. 2018, 10, 6-10. [CrossRef]

38. Houzelot, V.; Laubie, B.; Pontvianne, S.; Simonnot, M.O. Effect of up-scaling on the quality of ashes obtained from hyperaccumulator biomass to recover Ni by agromining. Chem. Eng. Res. Des. 2017, 120, $26-33$. [CrossRef]

39. Hazotte, C.; Laubie, B.; Rees, F.; Morel, J.L.; Simonnot, M.O. A novel process to recover cadmium and zinc from the hyperaccumulator plant Noccaea caerulescens. Hydrometallurgy 2017, 174, 56-65. [CrossRef]

40. Anastas, P.T.; Warner, J.C. Green Chemistry: Theory and Practice; Oxford University Press: New York, NY, USA, $1998 ; 148 \mathrm{p}$.

41. Anastas, P.T.; Zimmerman, J.B. Peer reviewed: Design through the 12 principles of green engineering. Environ. Sci. Technol. 2003, 37, 94A-101A. [CrossRef] [PubMed]

42. Waterlot, C.; Hechelski, M. Benefits of ryegrass on multicontaminated soils Part 1: Effects of fertilizers on bioavailability and accumulation of metals. Sustainability 2019, 11, 5093. [CrossRef]

43. Savio, M.; Cerutti, S.; Martinez, L.D.; Smichowski, P.; Gil, R.A. Study of matrix and spectral interferences in the determination of lead in sediments, sludges and soils by SR-ETAAS using slurry sampling. Talanta 2010, 82, 523-527. [CrossRef]

44. Waterlot, C.; Douay, F. The problem of arsenic interference in the analysis of Cd to evaluate its extractability in soils contaminated by arsenic. Talanta 2009, 80, 716-722. [CrossRef]

45. Waterlot, C.; Bidar, G.; Pruvot, C.; Douay, F. Analysis of cadmium in water extracts from contaminated soils with high arsenic and iron concentration levels. J. Environ. Sci. Eng. 2011, 5, 271-280.

46. Waterlot, C.; Couturier, D.; Hasiak, B. Friedel-Crafts benzylation of 1,4-dialkoxybenzenes-Cleavage and rearrangement of esters and methoxymethyl ethers in $\mathrm{ZnCl}_{2}$ montmorillonite $\mathrm{K} 10$ clays. J. Chem. Res. 2000, 2000, 100-101. [CrossRef]

47. Waterlot, C.; Ghinet, A.; Hechelski, M.; Dufrénoy, P. Catalyseurs Organo-Minéraux Issus de Plantes Non-Hyper-Accumulatrices Ayant Poussés sur des Supports Contaminés Amendés ou non; Déclaration d'Invention déposée à la SATT Nord, M0488; SATT Nord: Lille, France, 2017. (In French)

48. Trost, B.M. The atom economy-A research for synthetic efficiency. Science 1191, 254, 1471-1477. [CrossRef]

49. Sheldon, R.A. The $E$ factor 25 years on: The rise of green chemistry and sustainability. Green Chem. 2017, 19, 18-43. [CrossRef]

50. Curzons, A.D.; Constable, D.J.C.; Mortimer, D.N.; Cunningham, V.L. So you think your process is green, how do you know? Using principles of sustainability to determine what is green-A corporate perspective. Green Chem. 2001, 3, 1-6. [CrossRef]

51. Guan, L.P.; Wei, C.X.; Deng, X.Q.; Sui, X.; Piao, H.R.; Quan, Z.S. Synthesis and anticonvulsant activity of $\mathrm{N}$-(2-hydroxyethyl) cinnamamide derivatives. Eur. J. Med. Chem. 2009, 44, 3654-3657. [CrossRef]

52. De Sarkar, S.; Grimme, S.; Studer, A. NHC catalysed oxidations of aldehydes to esters: Chemioselective acylation of alcohols in presence of amines. J. Am. Chem. Soc. 2010, 132, 1190-1191. [CrossRef] [PubMed]

53. Fowles, J.; Boatman, R.; Bootman, J.; Lewis, C.; Morgott, D.; Rushton, E.; van Rooij, J.; Banton, M. A review of the toxicological and environmental hazards and risks of tetrahydrofuran. Crit. Rev. Toxicol. 2013, 43, 811-828. [CrossRef]

54. Schlosser, P.M.; Bale, A.S.; Gibbons, C.F.; Wilkins, A.; Cooper, G.S. Human health effects of dichloromethane: Key findings and scientific issues. Environ. Health Perspect. 2015, 123, 114-119. [CrossRef]

55. Garg, P.; Milton, M.D. Sodium carbonate mediated regioselective synthesis of novel N-(hydroxyalkyl)cinnamamides. Tetrahedron Lett. 2013, 54, 7074-7077. [CrossRef]

56. Dufrénoy, P.; Rigo, B.; Waterlot, C.; Hechelski, M.; Daïch, A.; Ghinet, A. Valorization of New Eco-Catalysts in the Synthesis of Anti-Inflammatory Compounds; Journées des Jeunes Chercheurs de la Société de Chimie Thérapeutique; Faculté de pharmacie Châtenay-Malabry: Châtenay-Malabry, France, 2017. 
57. Bahmanpour, A.M.; Héroguel, F.; Baranowski, C.J.; Luterbacher, J.S.; Kröcher, O. Selective synthesis of dimethyl ether on eco-friendly K10 montmorillonite clay. Appl. Catal. A 2018, 560, 165-170. [CrossRef]

58. Grison, C.M.; Velati, A.; Escande, V.; Grison, C. Metallophytes for organic synthesis: Towards new bio-based selective protection/deprotection procedures. Environ Sci. Pollut. Res. 2015, 22, 5686-5698. [CrossRef]

59. Escande, V.; Renard, B.L.; Grison, C. Lewis acid catalysis and green oxidations: Sequential tandem oxidation process induced by Mn-hyperaccumulating plants. Environ. Sci. Pollut. Res. 2015, 22, 5633-5652. [CrossRef] 